
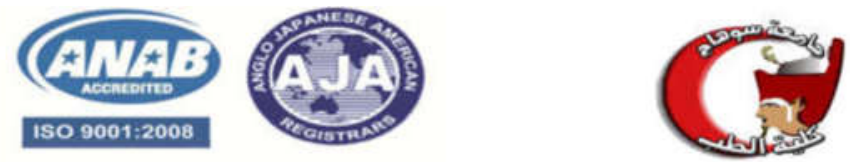

\title{
Sohag MEDICAL JOURNAL
}

\author{
Sohag University \\ Sohag Faculty of Medicine
}

ISSN $1687-8353$

Online home page: http://www.smj.journals.ekb.eg/

Official email address : smj2019@med.sohag.edu.eg

Vol. (23) No. (1)

Jan 2019 